\title{
Majoon Supari Paak - A Polyherbal Unani Formulation Used in the Management of Sayalan al-Rahim (Leucorrhoea)
}

\author{
Fouzia Bashir ${ }^{1 *}$, Jamal Akhtar ${ }^{2}$, Nighat Anjum ${ }^{2}$ and Shah Alam ${ }^{1}$ \\ ${ }^{1}$ Research Associate, Central Council for Research in Unani Medicine, Janakpuri, \\ New Delhi, India \\ ${ }^{2}$ Research Officer, Central Council for Research in Unani Medicine, Janakpuri, New \\ Delhi, India \\ *Corresponding Author: Fouzia Bashir, Research Associate, Central Council for \\ Research in Unani Medicine, Janakpuri, New Delhi, India.
}

\author{
Received: December 13, 2021 \\ Published: January 20, 2022 \\ (C) All rights are reserved by Fouzia Bashir., \\ et al.
}

\begin{abstract}
The Unani Medicine (Greek medicine) is a broad system of medicine, which specifically deals with a variety of states of wellbeing and disease. It deals in prevention of disease so that it can be checked in early stages and also helps to restore the function of body. This System of medicine is one of the oldest conventional systems of medicine, which has its root from the time of Hippocrates (460 - 377 BC). In modern medicine, Leucorrhoea is described as a thick discharge from vagina which is whitish, or yellowish in colour. It is commonly a non-pathological symptom which occurs after inflammation of the vagina or cervix. In Unani system of medicine, the modern counterpart name for leucorrhoea is Sayalan al-Rahim. A huge number of drugs, either single or compound formulations, have been described for the management of Sayalan al-Rahim. Majoon Supari Paak is a polyherbal Unani formulation that contains twenty-five herbal ingredients, of which Foful (Areca catechu) is the main ingredient along with Zafran (Crocus sativus), Darchini (Cinnamomum zeylenicum), Zanjabeel (Zingiber officinalis), Qaranfal (Cinnamomum verum) and many more. The medicine has been used to treat leucorrhoea, as a uterine tonic and also to treat infertility along with different gynaecological disorders. The ingredients have been considered to perform as an antioxidant, anti-inflammatory, and boost fertility. Scientific researches of the above-mentioned constituents have also reinforced their beneficial anti-inflammatory, astringent, and antiseptic properties.
\end{abstract}

Keywords: Majoon Supari Paak; Leucorrhoea; Sayalan al-Rahim; Unani Medicine

\section{Introduction}

From the time when mankind exists, it has been correlated with the factors of pain, illness and death and has been caught up with the question of domineering and eradicating the ailments of existence [1-3]. The Unani System of Medicine (USM) believes in the self-resistance ability (Tabi'at) of the individual. Unani Medicine's approach in dealing with the disease is quite different.

USM believes that the actual physician is the body's natural power of healing and maintaining its normal state of health (Tabi'at). This system is one of the long-established systems of medicine, which originates from the period of Buqrat (460 - 377
BC). It is based on the theory of four temperaments (Mizaj) and four humours (Akhlat), anticipated by Buqrat, who is also known as "Father of Unani medicine". This system particularly seeks to prevent diseases by means of certain drugs which can be of plant, animal or mineral origin. Various modes of treatment which are mentioned in Unani classical literature are four that is Pharmacotherapy (Ilaj-Bil-Dawa), Dietotherapy (Ilaj-Bil-Ghidha), Regimenal therapy (Ilaj-Bil Tadbeer), and Surgery (Ilaj-Bil-Yad) [4].

In USM, many herbs are used for centuries to manage Sayalan al-Rahim and a variety of other gynecological diseases which have Muhallil al-waram (anti-inflammatory), Qabiz (astringent), and 
Dafi-i- 'ufunat (antiseptic) properties. "Majoon Supari Paak" is one of the age-old Unani formulations used by Unani physicians in diseases especially for women. It helps to provide strength, treats symptoms associated with monthly problems like backache, anxiety, uneasiness, and bodily fatigue [5-8].

\section{Material and Methods}

The Google scholar, Embase, Science Direct,and Pubmed databases were searched toreview literature related to Leucorrhoea. A review of Urdu version of Unani literary books was also carried out to search for a description of Leucorrhoea and its aetio-pathogenesis by utilizing certain Unani manuscripts e.g., Al-Qanoon fit Tibb, Dhakhira Khawārizm Shāhi, Ikseer e Azam, Kitāb al Mansūrī, Al-asbab wal ala'mat, Kitāb al-Kulliyyāt, and Ghina Muna.The literary review of "Majoon Supari Paak" was carried by using standard Unani pharmacopeial manuscripts such as "Makhzanul mufradat maroof ba khawasul advia", "Qarabadeen Qadri", "Kamil al Sanaa", "Qarabadeen Najmul Ghani”, "Al Qarabadeen”, Al Hawi, Firdaus al Hikmat and Tibb-e-Akbar etc. Above mentioned databases were also utilized to explore new studies on ingredients of "Majoon Supari Paak" by searching through their frequent and botanical name for their astringent, anti-inflammatory, and antiseptic actions.

\section{Concept of leucorrhoea in modern medicine}

Leucorrhoea can be defined as an abnormal discharge from vagina. It is a frequent gynaecological complaint of women that involves more than $1 / 4^{\text {th }}$ gynae patients who visit the gynaecologist [1]. The discharge may vary from normal to excess flow, which might lead to a few ailments. It could be yellowish, stained with blood or may be contaminated with urine or stool [2]. The usual discharge is in fact a liquid form that is constituted of all worn out and dead cells from the vaginal area with other contaminated materials. The unusual discharge from vagina can be pale white, with a yellowish tint, reddish or blackish in colour [3]. Bad smell discharge from vagina makes an awkward position for women to move in public gatherings and even to keep in their private relationships. The unusual condition of the reproductive organs of women, if not treated in the preliminary stages, may become persistent and leads to PID (Pelvic Inflammatory Diseases), which is a cause of infertility. Women who suffer from pale colour vaginal discharge are not capable to conceive [1]. Strange vaginal discharge is usually linked with body aches and thirst [1]. Excessive vaginal discharge is physiological when linked with various phases of menstrual cycle. However, when it changes into pathological state, it produces oth- er trouble like low back pain, itching, burning sensation of vulva, poor desire for food, uneasiness, generalised weakness and pain in legs etc. Persistent poor health, tiredness, malnutrition, emotional conflict, unhealthy condition, inappropriate diet, constipation and chronic retro-verted uterus are responsible for excessive vaginal discharge. The most frequent reason of disproportionate discharge is physiological which is due to increase in conditions, when the oestrogen levels become high during the puberty, menstruation cycle, pregnancy and sexual excitement; followed by vaginal and cervical causes. Vaginal infections are because of microorganisms, viruses, fungi and some parasites. Other reasons comprise of foreign bodies, cervicitis, and atrophic vaginitis $[2,10]$. Infections of vaginal mucosa caused by Trichomonas vaginalis and Candida are the most frequent cause of excessive vaginal discharge. These are curable as well as preventable causes as both these infections are transmitted sexually. However, $25 \%$ of both infections are without any symptom [10].

\section{Concept of leucorrhoea in unani medicine}

The word leucorrhoea is originated from Greek word (leukos which means white) and (rhoia which means flow) [9]. In the Unani system of medicine "Sayalan al-Rahim" means excessive uterine discharge. The concept of Sayalan al-Rahim existed even in ancient era. In the age of Buqrat (Hippocrates) Sayalan al-Rahim (leucorrhoea) was referred as the flowing away of seeds of women. According to Arastu (Aristotle) opinion, distinguishing Suzak (Gonorrhoea) from Sayalan al-Rahimis difficult in females. Jalinoos (Galen 130-200 AD) said that Sayalan al-Rahim gave rise to Suzak $[10,45]$.

Majoosi (930-994 AD) described that Sayalan al-Rahim is an excessive discharge from the uterus. This discharge is secreted directly by the uterus due to the weakness of the Quwat e jazeba. Sometimes the waste of the body passed out through the uterus. The wastes of the body (fuzlat) are diverted towards the uterus in order to eliminate them by natural means (istefragh). It is the cleaning of the body; the type of discharge can be assessed on the basis of its color [7].

Razi (Razes 850-925 AD) has given a comprehensive description of this disease. According to him, sometimes excessive body fluid is evacuated as Sayalan al-Rahim. There will be bad odor discharge if there is an infection in the uterus [11].

According to Ibn Sina (Avicenna 980-1037 AD) uterus contains excessive waste products, and recurrent occurrence of infection 
leads to weakening of Quwate Hazema (digestive faculty) of uterine vessels which results in Sayalan al-Rahim [5].

Ismail Jurjani defined that unnecessary flow of uninfected discharge from the uterus is known as Sayalan al-mani and drift of infected discharge is labeled as Sayalan al Rahim [12].

Ibn Hubal mentioned that ejection in Sayalan al-Rahim is a waste product of the uterus. Discharge is usually phlegmatic, viscous, and sometimes watery [8].

Another renowned physician Akbar Arzani quoted that Sayalan al-Rahim is a continuous- discharge from the uterus which is due to the weakness of the nutritive ability of the uterus. This discharge may be phlegmatic, or bilious in nature [13].

Azam Khan specified that Sayalan al-Rahim is produced due to the deprived nutritive facility of the uterus or maybe the occurrence of extra products in the body. This undue waste product of the body is ejected from the uterus or through the vagina which is termed as istafragh [14].
Ajmal Khan (1868-1927 AD), mentioned that Sayalan al-Rahim is a disease that badly marks the wellbeing of women and must not be ignored as it can disturb the vital organs along with the productiveness of a woman [15].

Hasan Qarshi specified that Sayalan al-Rahim is the secretion from the mucosa of uterus and vagina. Qarshi also mentioned that vaginal cells also exist in the discharge [16].

“Majoon Supari Paak” as prophylactic medicine against leucorrhoea

\section{Background of "Majoon Supari Paak"}

Unani literature suggests that Unani scholars were well experienced in diagnosing and managing gynecological disorders. By their immense bits of knowledge, they used numerous medicinal plants as preventive medicine for diseases related to women. The Unani physicians have castoff these single and compound Unani medicines in healthy as well as ill people and found positive results. "Majoon Supari Paak" is one of the compound formulations that is used by Unani practitioners $[12,44]$.

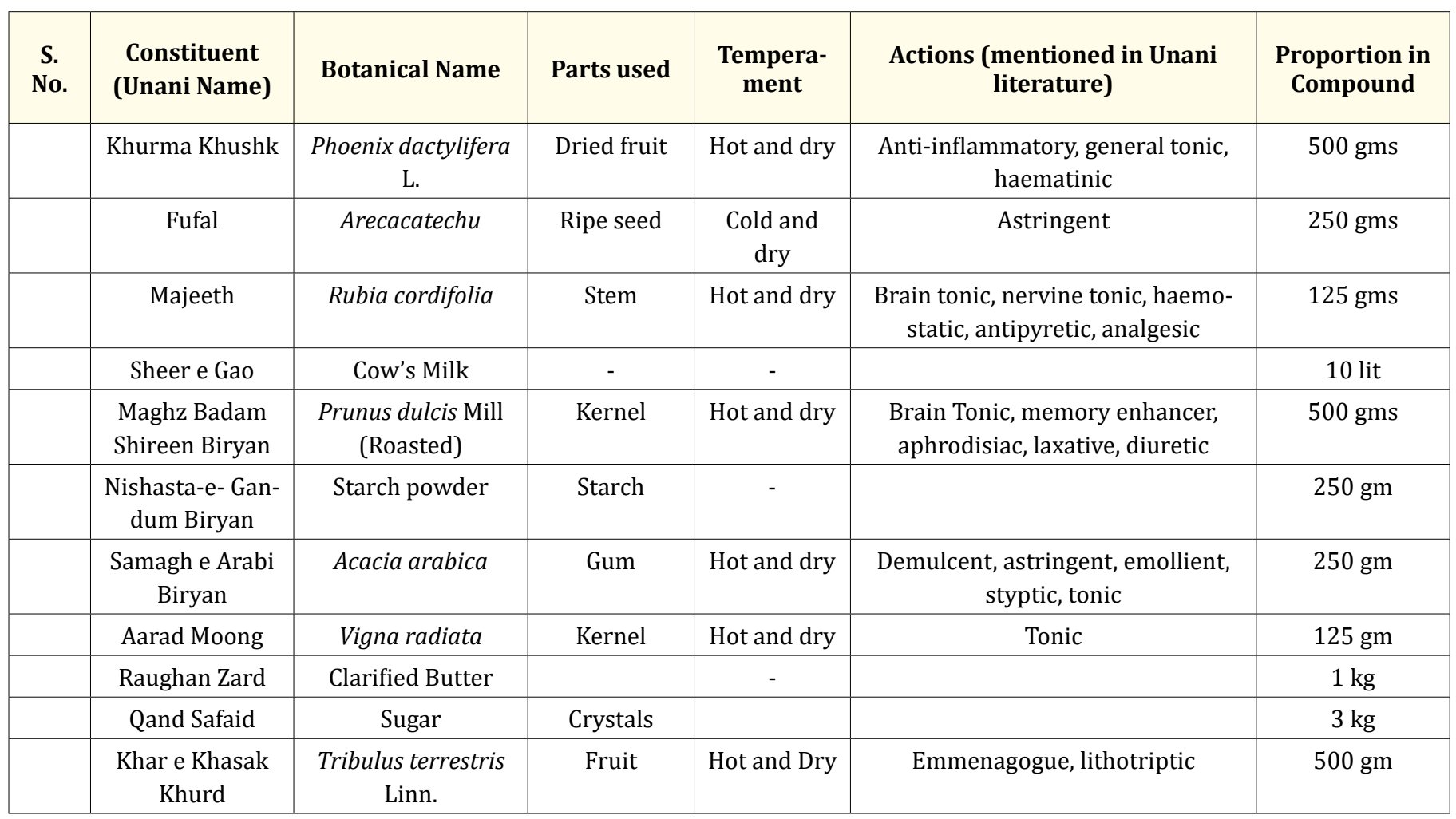


Majoon Supari Paak - A Polyherbal Unani Formulation Used in the Management of Sayalan al-Rahim (Leucorrhoea)

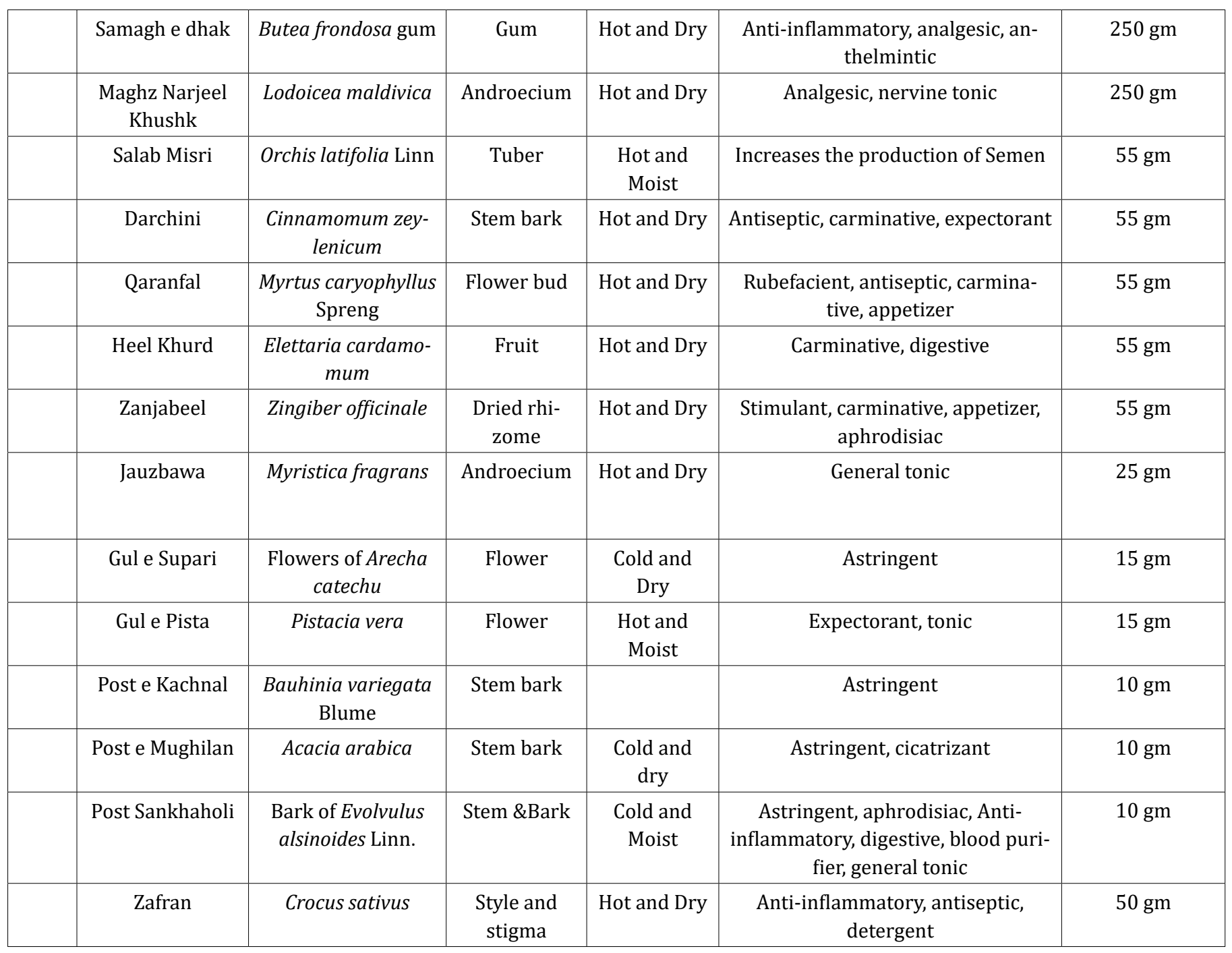

Table 1: Constituents of Majoon Supari Paak [17].

\section{Method of preparation of "Majoon Supari Paak"}

For preparing Majoon, Qiwam (base) of diverse consistencies (tar) is commonly made. It totally lies on the type of ingredient drugs that are used. The qiwam is mostly completed by the addition of Aab (water), Araq (distillate) or Aab e samar (fruit juices), etc in any of the bases of purified honey, sugar, candy or jaggery, etc. Thereafter, it is boiled on low heat till it attains the essential consistency. The bases are mostly decontaminated by adding Aab e lemu (lemon juice), Satt e lemu (extract of lemon), or Shib e yamani (Alum) before producing perfect qiwam. Then the constitu- ents are mixed in qiwam to make Majoon. Qiwam for majoon is of two tar (consistency) [18-21]. Majoon Supari Paak is formulated in the same manner until proper qiwam (consistency) of two tar is achieved [22,23]. All the dry ingredients, after being crushed together and sifted through 80-mesh, are ended into a sufoof (powder). When the appropriate qiwam (consistency) forms, the powdered ingredients are slowly mixed to it during stirring till both blends properly. The freshly prepared "Majoon Supari Paak" is preserved in glass jar [18-21]. Photographs of some of the ingredients of Majoon Supari Paak are here with. 


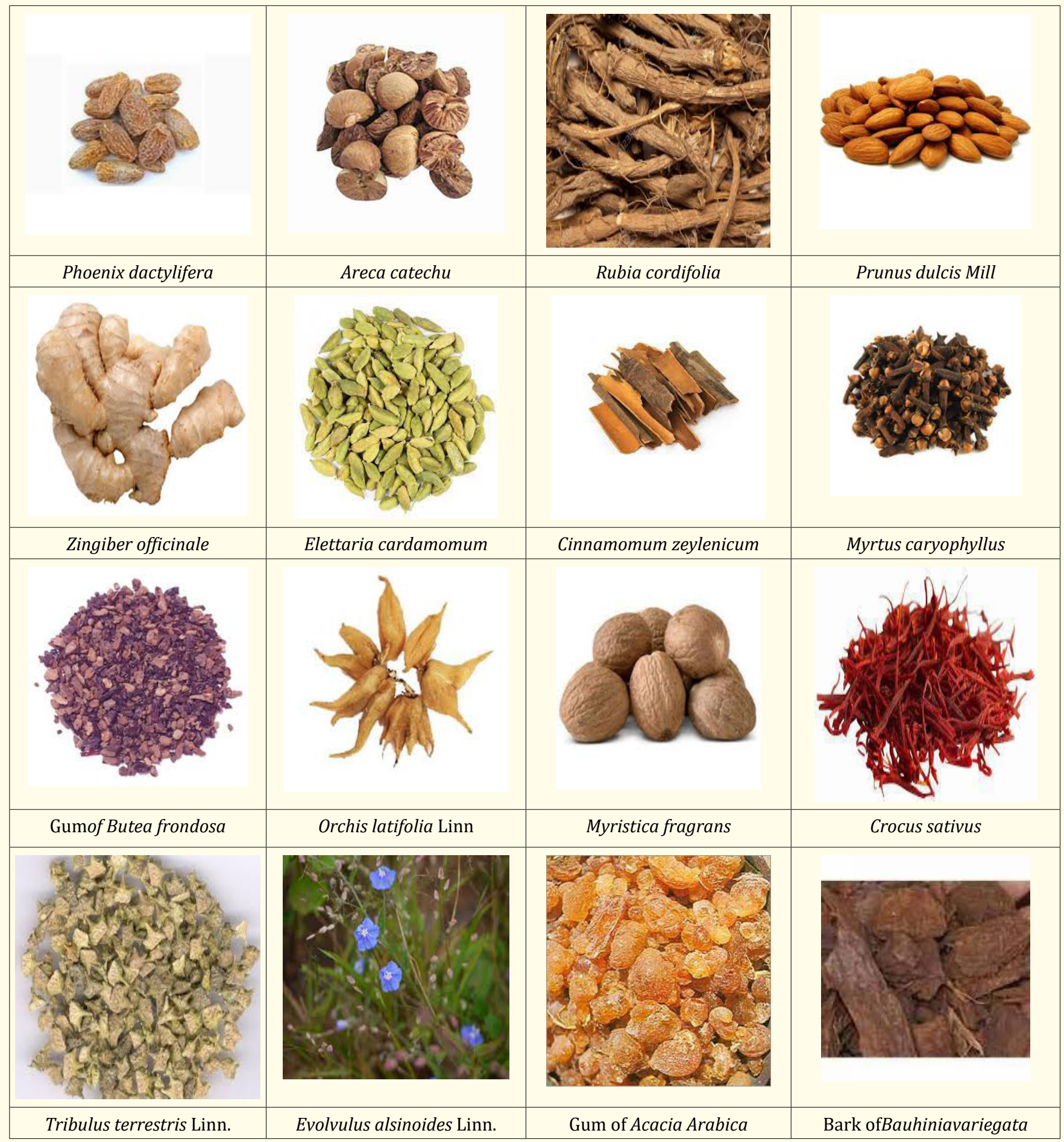

Figure 1 
The dose of "Majoon Supari Paak" and expiry

10 - 15g of Majoon Supari Paak with lukewarm water is generally advised. Renowned physicians of the Unani system specified that the effectiveness of "Majoon Supari Paak" remains for two years. Though, they have not revealed the temperature and state of packing where it can be kept for up to 2 years [22].
Actions and indications of usage of "Majoon Supari Paak"

Many Unani scholars, including Ibn Sina and Akbar Arzani advised using Majoon Supari Paak in a variety of conditions such as to improve sexual debility, premature ejaculation, leucorrhoea. It also improves the functions of liver, spleen and helps the uterus in the implantation of the foetus. It also helps in the delivery of a child [22].

Physicochemical standards of Majoon Supari Paak [24]

\begin{tabular}{|l|c|}
\hline Appearance & Semi-solid \\
\hline Colour & Brown \\
\hline Smell & Pleasant \\
\hline Taste & Sweet \\
\hline Alcohol soluble matter & $45.92-49.84 \%$ \\
\hline Water soluble matter & $48.72-51.20 \%$ \\
\hline Successive extractives & \\
\hline Pet. Ether & $16.75-18.20 \%$ \\
\hline Chloroform & $0.19-0.23 \%$ \\
\hline Ethanol & $1.56-1.91 \%$ \\
\hline pH of $1 \%$ aq soln & $5.85-6.36$ \\
\hline pH of $10 \%$ aq soln & $5.25-5.96$ \\
\hline Bulk density & 1.33 \\
\hline Total ash & 3.7 mg $\%$ \\
\hline Water soluble ash & \\
\hline Acid insoluble ash & $3.70 \%$ \\
\hline Volatile oils & $0.24-0.45 \%$ \\
\hline Alkaloids & $1.13-1.94 \%$ \\
\hline Tannins & $0.30 \% \mathrm{v} / \mathrm{w}$ \\
\hline Resins & $0.27 \%$ \\
\hline Reducing sugars & $0.75 \%$ \\
\hline Crude fibres & $0.58 \%$ \\
\hline Total Nitrogen & $52.3 \%$ \\
\hline Sodium & $2.6 \%$ \\
\hline Potassium & $\mathrm{mg} \%$ \\
\hline Calcium & \\
\hline Phosphates & \\
\hline
\end{tabular}

Table 2

\section{Evidence-based research}

Table 3 signifies a summary of evidence-based research on a few ingredients of "Majoon Supari Paak" showing anti-inflammatory, anti-fungal/anti-bacterial/anti-microbial and astringent activities. 
Components of "Majoon Supari Paak"

\begin{tabular}{|c|c|c|c|c|}
\hline S. No. & Ingredients & Anti-inflammatory & $\begin{array}{l}\text { Anti-fungal/anti- bacte- } \\
\text { rial/anti- microbial }\end{array}$ & Astringent \\
\hline & Khurma Khushk & $\begin{array}{l}\text { The ethyl acetate, methanolic, } \\
\text { and water extracts of Ajwa dates } \\
\text { inhibited the lipid peroxidation } \\
\text { cyclo-oxygenase enzymes COX-1 } \\
\text { and COX2 which shows their anti- } \\
\text { inflammatory property [25]. }\end{array}$ & $\begin{array}{l}\text { The methanol and acetone } \\
\text { extract of the P. dactylifera } \\
\text { pits inhibited the growth of } \\
\text { Gram-positive and Gram- } \\
\text { negative bacteria }[26,27] \text {. }\end{array}$ & $\begin{array}{c}\text { A study on Phoenix dactilyfera } \mathrm{L} \text {. } \\
\text { seed extract showed the presence } \\
\text { of good number of tannins which } \\
\text { are responsible for its astringent } \\
\text { activity [28]. }\end{array}$ \\
\hline & Fufal & $\begin{array}{l}\text { The ethanolic extract of A. } \\
\text { catechu at a dose of } 250,500, \\
\text { and } 1000 \mathrm{mg} / \mathrm{kg} \text { p.o. produced } \\
\text { dose-dependent and significant } \\
\text { anti-inflammatory and analgesic } \\
\text { activities [29]. }\end{array}$ & $\begin{array}{l}\text { The Areca nut extract } \\
\text { inhibited } 100 \% \text { growth } \\
\text { of single-cell fungus e.g. } \\
\text { Candida albicans [30]. }\end{array}$ & $\begin{array}{l}\text { Tannins are one of the most dis- } \\
\text { tinctive constituents of } A \text {. catechu } \\
\text { which inhibit lipid peroxidation, } \\
\text { thus activating the inhibition of } \\
\text { cyclooxygenase, responsible for } \\
\text { the astringent activity [31]. }\end{array}$ \\
\hline & Samagh e Arabi & $\begin{array}{l}\text { The ethyl acetate fraction was } \\
\text { found to contain yellow pigment } \\
\text { "isoquercetin" which was found } \\
\text { to have promising results with } \\
\text { respect to acute and chronicanti- } \\
\text { inflammatory studies [36]. }\end{array}$ & $\begin{array}{l}\text { The crude methanolic plant } \\
\text { extract } \\
\text { of A. arabica showed } \\
\text { considerable anti-fungal } \\
\text { activity against } \\
\text { Streptococcus cereviceae } \\
\text { [35]. }\end{array}$ & $\begin{array}{l}\text { A single-blind, RCT on } 45 \text { married } \\
\text { women } \\
\text { With the abnormal vaginal dis- } \\
\text { charge was carried out in which } \\
\text { decoction of Chal babool showed } \\
\text { significant } \\
\text { improvement against } \\
\text { standard drug Tab. Metronidazole } \\
\text { (400 mg } \\
\text { twice daily) in the } \\
\text { management of Bacterial Vagino- } \\
\text { sis (P = 1.000) statistically [34]. } \\
\text { An RCT was conducted to evalu- } \\
\text { ate the efficacy of Acacia arabica } \\
\text { powder in } \\
\text { Uterine Prolapse cases. The drug } \\
\text { showed significant improvement } \\
\text { due to the presence of tannins }\end{array}$ \\
\hline
\end{tabular}




\begin{tabular}{|c|c|c|}
\hline Samagh e dhak & $\begin{array}{l}\text { The methanolic extract of leaf } \\
\text { of } B \text {. monosperma at the dose } \\
\text { level of } 400 \mathrm{mg} / \mathrm{kg} \text { body weight } \\
\text { exhibit significant }(\mathrm{P}<0.05) \\
\text { anti-inflammatory activity against } \\
\text { carragenan induced paw edema in } \\
\text { rats [38] }\end{array}$ & $\begin{array}{l}\text { The ethanolic extract of } B . \\
\text { monosperma exhibits anti- } \\
\text { bacterial action against } \\
\text { B. subtilis, S. typhimurium, } \\
\text { S. aureus, } P \text {. vulgaris. and E. } \\
\text { coli }[39]\end{array}$ \\
\hline Post Sankhaholi & $\begin{array}{l}\text { The ethanolic, chloroform and } \\
\text { ethyl acetate extracts of Evolvulus } \\
\text { alsinoides showed anti-inflam- } \\
\text { matory activity with graded dose } \\
\text { response on formalin induced } \\
\text { paw odema in rats [42]. }\end{array}$ & $\begin{array}{l}\text { In a study carried out on } \\
\text { methanolic extract Evol- } \\
\text { vulus alsinoides showed a } \\
\text { clear antibacterial effect } \\
\text { against Methicillin sensitive } \\
\text { Staphylococcus aureus [43]. }\end{array}$ \\
\hline
\end{tabular}

Table 3

\section{Conclusion}

Unani physicians were well aware of the gynaecological problems related to women. Therefore, they formulated certain Unani preparations such as "Majoon Supari Paak" to prevent and manage various diseases. Constituents of "Majoon Supari Paak" have proved their effectiveness against uterine problems, which are not only found in married women but also in teenagers and young women, besides its anti-inflammatory and astringent potential. It's very unfortunate that Unani system needs more attention and further logical research so that it would be explored for its benefits in the management of uterine problems which upgrade humanity.

\section{Authors' Contribution}

Fouzia Bashir developed the original idea of writing "Majoon Supari Paak" in management of Leucorrhoea as a manuscript. Introduction, the Unani concept of Leucorrhoea, review of "Majoon Supari Paak" were written by Fouzia Bashir, Shah Alam, Jamal Akhtar and Nighat Anjum. The modern concept of Leucorrhoea was written by Fouzia Bashir. Scientific study on "Majoon Supari
Paak" constituents was written by Fouzia Bashir and Shah Alam. All of the authors did the final review of the manuscript.

\section{Conflict of Interests}

The authors declare no conflict of interest.

\section{Funding/Support}

This literary study did not receive any funding or support.

\section{Acknowledgment}

We are thankful to the DG, Central Council for Research in Unani Medicine for providing the facilities.

\section{Bibliography}

1. Berek and Nowak textbook of gynaecology. $15^{\text {th }}$ edition, chapter 18: 557-570.

2. D C Dutta. Text Book of Gynaecology, Chapter, 33, 142-154, 524-526. 
3. Hawkins and Bournes shaw textbook of gynaecology. $15^{\text {th }}$ edition, Chapter, 10, 11, 12, 150 .

4. Kabeeruddin Mohd and Al Akseer. Vol II, Aijaz Publishing House, New Delhi. (2003): 1372 -1374.

5. Ibn Sina. Al-Qanoon Fit-Tib. Urdu trans. by Kantoori, G.H. Idarae Kitabush shifa New Delhi. 2 (2007): 341.

6. Razi Abu Bakar. Al Hawi fit tib vol. 9. Urdu trans. by CCRUM New Delhi. 8 (2001): 14-15.

7. Majoosi Ali bin Abbas. Kamilus Sana. Urdu trans by Kantoori G H Munshi Nawal Kishore, Lucknow. 1889; 182-184, 534-553.

8. Ibn Hubal Baghdadi. Kitab Al Mukhtarat fit Tibb vol. 4. Urdu trans by Central Council for Research in Unani System of Medicine New Delhi 37 (2007).

9. Qarshi MH. Jamiul Hikmat part 2. NA: 1073-1077.

10. Michael J O'Dowd and Elliot E. Philipp. "The History of Obstetrics and Gynaecology". Parthoron Publishing Group (2000): 191-193.

11. Razi Abu Bakar. Al Hawi fit tib vol. 9. Urdu trans. by CCRUM New Delhi 8 (2001): 14-15.

12. Jurjani AH. Dakhira Khwarzam Shahi (Urdu Tran: Khan AH), Vol VI, Idarae Kitabus Shifa, New Delhi (2010): 596, 607, 631.

13. Akbar Arzani. Tibbe Akbar. Idara kitabul-Shifa, Delhi: 457-458.

14. Khan Azam. Aikseer Aazam. Matba Munshi Nawal kishore Lucknow: 715.

15. Khan A. Haziq, Madina Publication Karachi, New Delhi (1983): 481-483.

16. Qarshi M. Jamu al-Hikmat, Vol I, Idarae Kitabus Shifa, New Delhi (2011): 1121-1123.

17. Anonymous. National Formulary of Unani Medicine, Part 1, Edn Urdu, Delhi, M.H.F.W Govt. of India, (1993): 123-326.

18. Arzani H M A. "Meezan ul Tib". (Urdu) $1^{\text {st }}$ Edition 178-81, 756.

19. Kabeeruddin H M. "Al Qarabadeen". CCRUM New Delhi (2006): 1212.

20. Kabeeruddin H M. "Al Qarabadeen". Vol II. Malik son's publishers, Faisalabad, (YNMa). 413.
21. Kabeeruddin H M. "Sharah Asbab". Vol III, Shaukat Book Depot, Gujrat, (YNMb). 180-186.

22. Khan M A. “Qarabadeen-e-Azam”. Aijaz Publishing House, New Delhi (1957): 576.

23. Khan M A. "Moheet-e-Azam". New Delhi: CCRUM 1 (2012): 213-215.

24. Anonymous. "Physicochemical standards of Unani formulations". Part $1^{\text {st }}$ New Delhi, CCRUM, (1986): 90.

25. Zhang CR., et al. "Antioxidant and anti-inflammatory assays confirm bioactive compounds in Ajwa Date fruit". Journal of Agricultural and Food Chemistry 61 (2013): 5834-5840.

26. Jassim SAA and Naji MA. "In vitro evaluation of the antiviral activity of an extract of date palm (Phoenix dactylifera L.) pits on a Pseudomonas phage". Evidence-Based Complementary and Alternative Medicine 7 (2010): 57-62.

27. Ammar NM., et al. "Flavonoid constituents and antimicrobial activity of date (Phoenix dactylifera L.) seeds growing in Egypt". In: Proceedings of 4th conference on research and development of pharmaceutical industries (Current Challenges). Medicinal and Aromatic Plant Science and Biotechnology 3 (2009): 1-5.

28. T Okuda., et al. "Hydrolyzable tannins and related polyphenols". Progress in the Chemistry of Organic Natural Products 66 (1995): 1-177.

29. Bhandare AM., et al. "Potential analgesic, anti-inflammatory and antioxidant activities of hydroalcoholic extract of Areca catechu L. nut". Food and Chemical Toxicology 48.12 (2010): 3412- 3417.

30. Anthikat R R N., et al. "Antifungal activity of Areca catechu L". International Journal of Pharmaceutical and Clinical Science 4.1 (2014): 1-3.

31. Zhang J., et al. "Molecular mechanisms for arecoline against atherosclerosis". Chinese Pharmacological Bulletin 20 (2004): 146-149.

32. Anar Patel., et al. "Evaluation of Anti-inflammatory and Analgesic activity of roots of Rubia cordifolia in rats". Journal of Pharmaceutical Sciences and Research 2.12 (2010): 809-813. 
33. Basu S., et al. "Evaluation of the antibacterial activity of Ventilago madraspatana Gaertn, Rubia cordifolia Linn. And Lantana camara Linn. Isolation of Emodin and Physcion as active antibacterial agents". Phytotherapeutic Research 19.10 (2005): 888-894.

34. Jahufer R and Begum W. "Efficacy of Bark of Acacia arabica in Management of Bacterial Vaginosis : A Randomized Controlled Trial". International Journal of Current Research and Review 6.1 (2014): 79-88.

35. Shazia M., et al. "Anti-Microbial screening of some medicinal plants extracts". International Journal of Research in Ayurveda and Pharmacy 2.4 (2011): 1258-1264.

36. Rajendran A., et al. "Phytochemical studies and pharmacological investigations on the flowers of Acacia Arabica". African Journal of Pure and Applied Chemistry 4.10 (2010): 240-242.

37. Farzana MUZN., et al. "Efficacy of Acacia Arabica in Improving Woman's Quality of Life in Uterine Prolapse: A Randomized Controlled Trial". Sri Lanka Journal of Indigenous Medicine 2.1 (2012): 101-106.

38. Swati Jain., et al. "Anti-Inflammatory Activity of Butea monosperma Leaves". Research Journal of Pharmacology and Pharmacodynamics 2.5 (2010): 351-352.

39. Jayasree D., et al. "Evaluation of antibacterial activity of ethanolic extract of Butea monosperma (Lam.) Kuntz pod". Journal of Pharmaceutical, Chemical and Biological Sciences 3.1 (2015): 01-05.

40. Santanu Saha., et al. "In Vivo Study for Anti-inflammatory Activity of Bauhinia variegata L. Leaves". Pharmaceutical Crops 2 (2011): 70-73.

41. Uddin G., et al. "Preliminary phytochemical, in vitro pharmacological study of Bauhinia alba and Bauhinia variegate flowers". Middle-East Journal of Medicinal Plants Research 4 (2012): 7579.

42. Purma Aravinda Reddy., et al. "Evaluation of anti-inflammatory activity of Evolvulus alsinoides plant extracts". Journal of Pharmaceutical and Scientific Innovation 2.3 (2013): 24-26.

43. Mahmood HZ. "Assessment of Phytochemicals and Antibacterial Activity of Evolvulus alsinoides". Clinical Microbiology: Open Access 10 (2021): 345.

44. Khan M. "Clinical study of Sailanur Rahem and its management with Unani formulation". MD Dissertation NIUM, Bangalore 9-17 (2007): 44-45.
45. Khadija Zahid Ali., et al. "Sailan-ur-Rahem (Abnormal Vaginal Discharge) in Greco-Arabic Medicine: A Review. Research and Reviews". A Journal of Unani, Siddha and Homeopathy 4.2 (2017): 1-6.

\section{Assets from publication with us}

- Prompt Acknowledgement after receiving the article

- Thorough Double blinded peer review

- Rapid Publication

- Issue of Publication Certificate

- High visibility of your Published work

Website: www.actascientific.com/

Submit Article: www.actascientific.com/submission.php

Email us: editor@actascientific.com

Contact us: +919182824667 